\title{
FEEDING BEHAVIOR OF THE AUSTRALIAN ACRIDID, VALANGA IRREGULARIS
}

BY

\author{
W. J. FREELAND \\ Department of Zoology, University of Michigan, Ann Arbor, Michigan 48104, U.S.A.
}

\begin{abstract}
Feeding experiments with the Australian acridid, Valanga irregularis, demonstrated the following relationships: 1) grasshoppers require a period of feeding on a particular food before becoming completely adjusted to it; 2) the plant species eaten has a strong influence on the rate of ingestion, even when the species is a preferred food in nature; 3 ) grasshoppers eat more food when feeding on a variety of foods than they do when restricted to a single plant species; 4) the rate of food ingestion at any particular time can be influenced greatly by foods the grasshopper has eaten previously and 5) the observed patterns were not due to differences between plant species' water content or leaf hardness. It is argued that the nutritional content of the leaf species cannot explain the observed feeding behaviors. The results of the feeding experiments coincide with those hypothesized by Freeland \& Janzen (1974) when considering the role of plant secondary compounds in determining the feeding behaviors of polyphagous mammals. It is suggested that plant secondary compounds are responsible for the observed feeding behavior of caged $V$.irregularis.
\end{abstract}

Polyphagous acridids tend to confine their feeding to either monocotyledonous or dicotyledonous plants (Bernays \& Chapman, 1970; Mulkern, 1967; Williams, 1954). Within one of these plant categories, individuals of particular acridid species exhibit definite food preferences. These may change from season to season and/or area to area (Bernays \& Chapman, 1970). Attempts to correlate plant physical characteristics (leaf shape, toughness, water content, etc.) with grasshopper food preferences have been partially successful (Chapman, 1957; Dadd, 1963; Pfadt, 1949; Scharff, 1954; Williams, 1954). The results, however, do not provide a complete understanding of the demonstrated food preferences or feeding behavior.

Consideration of mammalian physiological responses to toxic plant secondary compounds gave rise to a series of hypotheses as to the type of feeding behavior expected from polyphagous mammals (Freeland \& Janzen, 1974). There are often similarities in the ways generalist insects and mammals deal with foreign toxic compounds (Smith, 1955; Williams, 1959); it is possible that grasshopper feeding behavior is determined in much the same way as that of herbivorous mammals.

This paper describes experiments on the feeding behavior of a large polyphagous acridid, Valanga irregularis, and examines the roles of leaf toughness, leaf water content, and secondary plant compounds in its determination. V.irregularis is a large polymorphic grasshopper found throughout the lowland suburbs and farmlands of tropical and subtropical eastern Australia. 


\section{MATERIALS AND METHODS}

Records of plant species eaten by $V$.irregularis were taken in a suburban backyard in Ipswich, Queensland. The study area contained more than 40 species of cultivated or semi-cultivated dicotyledonous species. There was an undetermined number of weedy dicotyledons. In addition, there was an undetermined number of weedy and cultivated monocotyledonous species (lilies, grasses, orchids, aloes) and several species of fern. Observations of grasshopper feeding behavior were made daily between 9.00 and 12.00 hours. The grasshoppers became active soon after sunrise and spent long periods sunning themselves and eating. During the mid-day heat they retreatted to the shade. Feeding and sunnling resumed in the late afternoon and feeding usually ceased after dusk.

Feeding experiments were carried out on twenty individually housed grasshoppers. Cages were made of chicken wire, covered with mosquito netting, and suspended from a fig tree. The twenty adult grasshoppers were divided into four groups of five such that each group had at least one individual of each of the three most common color morphs ("concolorous", "contrasty", "maculicollis" (White, 1968)). A starvation period of 24 hours was used to ensure that all grasshoppers would eat when presented with experimental diets. The foods used in the experiments were mature non-senescent leaves of the four plant species most frequently eaten by free-living $V$. irregularis. Leaves were taken from only one individual of each of the four plant species. This individual plant was one that was known to have been eaten by grasshoppers. Bauhinia blakeana, Prunus domestica, Citrus limon and Hibiscus rosa-sinensis were the plant species used. The feeding experiments proceeded as follows:

Day 1. All individuals were captured, caged and not provided with any food.

Day 2. Group A: provided with B. blakeana leaves. Group B: provided with $P$. domestica leaves. Group C: provided with $C$. limon leaves. Group D: provided with $H$. rosa-sinensis leaves.

Day 3. The amount of leaf eaten by each of the grasshoppers was measured by tracing the leaves on graph paper and counting the empty squares. Each individual was given fresh leaves of the species it had been given during the previous 24 hours.

Day 4. Food was removed and the amount eaten was not recorded. No new leaves were provided.

Day 5. All individuals were given leaves of the species they had been given previously.

Day 6. Food was removed and the amount eaten was recorded. No fresh food was given.

Day 7. Each grasshopper was given leaves of all four plant species.

Day 8. The amount of each leaf species each grasshopper had eaten was recorded and fresh food of all four species was provided.

Day 9. Old food was removed and fresh leaves of all species added to each cage. 
Day 10. All food materials were removed and not replaced. Records were taken of which plant species each grasshopper had eaten.

Day 11. Fresh leaves of all species were given to each grasshopper.

Day 12. The amount of each species eaten by each individual was recorded, and the grasshoppers were liberated.

Leaf thickness differed among the plant species used in the feeding experiments. Leaf surface areas eaten by grasshoppers were converted into dry weights by drying $\left(60-70^{\circ} \mathrm{C}\right)$ predetermined leaf areas of each species. This also gave an estimate of the water content of each species.

To obtain an index of leaf toughness, a "penetrometer" was constructed (Feeny, 1970; Williams, 1954). The plunger used had a diameter of $4 \mathrm{~mm}$.

\section{RESULTS}

Food selection. Table I lists the plant species eaten by $V$.irregularis and the number of grasshoppers observed eating each species. Grasshoppers were not seen eating monocotyledons although grasshopper feeding damage was seen on a lily and an aloe. Only sixteen of the more than 40 species of dicotyledonous plants were observed to be eaten.

TABLE I

Plant species eaten by Valanga irregularis

$\begin{array}{lclc}\text { Plant species } & \begin{array}{c}\text { No. of } \\ \text { observations }\end{array} & \text { Plant species } & \begin{array}{c}\text { No. of } \\ \text { observations }\end{array} \\ \text { Bauhinia blakeana } & 25 & \text { Jasminum sp. } & 11 \\ \text { Cassia coluteoides } & 14 & \text { Lagerstroemia indica } & 1 \\ \text { Citrus limon } & 49 & \text { Morus } \text { sp. } & 1 \\ \text { Datura candida } & 1 & \text { Pelargonium sp. } & 8 \\ \text { Eriobotrya japonica } & 10 & \text { Plumbago capensis } & 13 \\ \text { Ficus sp. } & 2 & \text { Plumeria rubra } & 10 \\ \text { Hibiscus rosa-sinensis } & 32 & \text { Prunus domestica } & 20 \\ \text { H. syriacus } & 14 & & \end{array}$

$V$. irregularis exhibited strong food preferences, totally avoiding most of the plant species potentially available to it. More than half of the feeding observations were accounted for by only four plant species. These species (B. blakeana, $P$. domestica. $C$. limon, $\boldsymbol{H}$. rosa-sinensis) were approximately equally abundant and were neither the most nor least abundant plants in the study area. One grasshopper died during the experiments.

Feeding experiments. The quantity of leaf eaten by grasshoppers was expressed as grams dry weight of leaf per 100 units of body size. The length of the pronotum was used as an indicator of body size. Average amounts of food eaten on days 1 , 5, 7, and 11 are shown in Fig. 1E. There was a significant increase in the average amount eaten each day from day 7 to day $11(\mathrm{t}=3.39, \mathrm{p}<0.005$ ). The average 

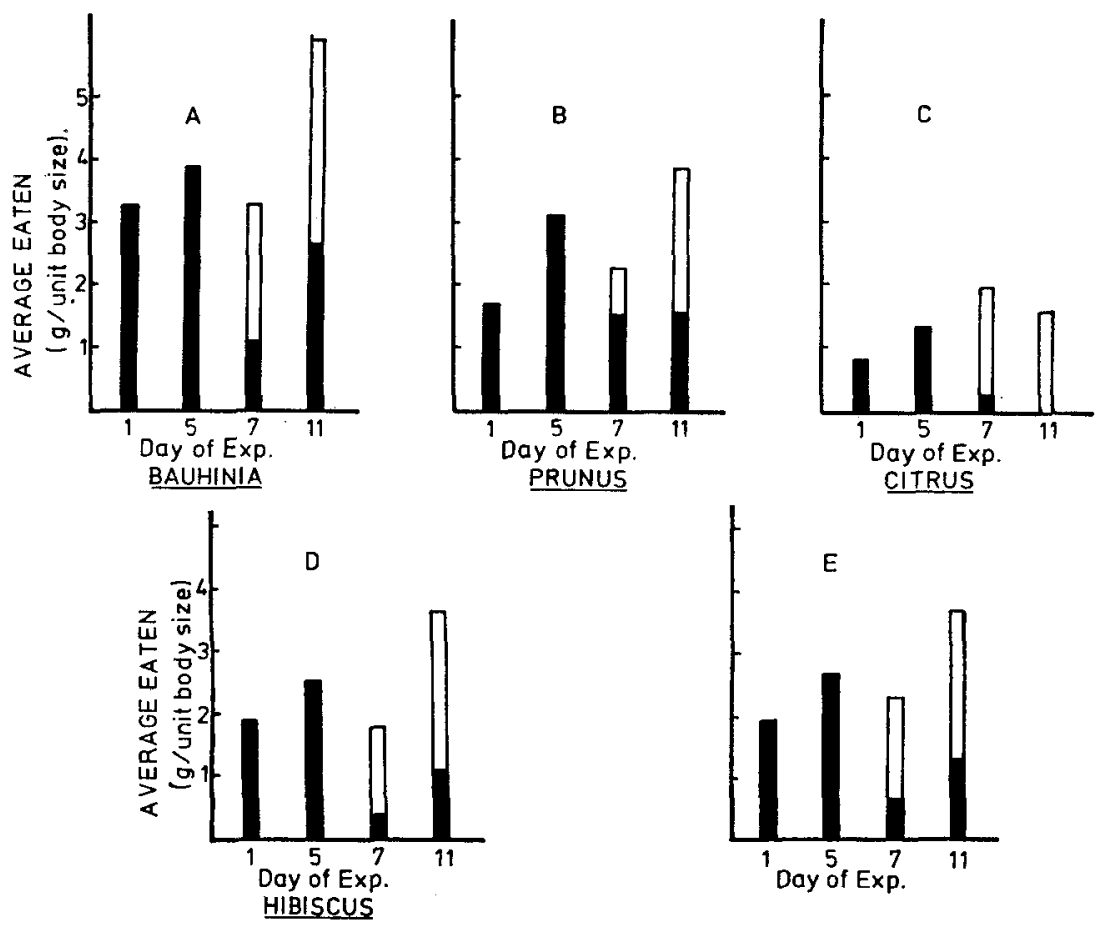

Fig. 1. Average amounts eaten each day by grasshoppers in each of the four groups. The shaded portion is the amount eaten of the species provided during the first half of the experiment. Unshaded areas indicate the amounts eaten of the three additional species provided during the second half of the experiment. (A) = group fed Bauhinia; (B) = group fed Prunus; (C) = group fed Citrus; (D) = group fed Hibiscus; (E) $=$ average of all groups.

amount of leaf eaten on day 11 was also significantly greater than that eaten on day $5(\mathrm{t}=2.1, \mathrm{p}<0.025)$. When presented with either a single plant species or four different plant species, the grasshoppers ate more food after a period of time than they did on the first day with that food. When allowed to feed on four foods for a period of time, the grasshoppers ate more on average than when they were forced to feed on a single plant species (Fig. 1E). The effect the number of foods eaten has on the total quantity ingested is also reflected in the behavior of individual grasshoppers. On day 7 those individuals that ate three or four foods, ate significantly more than those feeding on one or two species $(t=3.12, p<0.005)$. A similar result was found on day $11(t=3.98, p<0.005)$.

When grasshoppers were fed a single plant species, the species fed had a significant effect on the quantity eaten (day $5: \mathrm{F}=18.25>\mathrm{F}_{3,15}=5.42$ at $\mathrm{p}=0.01$ ). On day 5, grasshoppers fed $B$. blakeana ate more than those fod $P$. domestica, which ate more than those fed $H$. rosa-sinensis, which ate more than those fed C. limon. On day 11 the amounts eaten by each group were again significantly different $\left(F=14.42>F_{3,15}=5.42\right.$ at $\left.p=0.01\right)$. The direction of this difference 
was the same as that observed on day 5. The species of plant grasshoppers were fed when given a single food affected both the amount ingested while feeding on that food and their subsequent rates of ingestion. This effect is best illustrated by a comparison of the feeding behavior of $V$. irregularis fed B. blakeana, with that of individuals given $C$. limon. When given only Citrus leaves, grasshoppers ate less than grasshoppers fed other single plant species. When presented with foods in addition to Citrus, these grasshoppers sampled the new foods. By day 11 , all five individuals had ceased to eat Citrus, but were still eating less than the other groups. In contrast, grasshoppers fed B. blakeana ate more than the other grasshoppers during the first half of the experiments. When provided with three additional foods, they continued to feed on B. blakeana. In addition, they sampled some of the alternative foods provided and continued to eat more than grasshoppers in the other groups. However, only two of the five individuals were eating Citrus on day 11. The other groups exhibited feeding behaviors similar to those fed B. blakeana. They either avoided Citrus after having sampled it or they ate extremely small quantities of it. The species of leaf fed to $V$.irregularis affected the quantity of food ingested per unit time and had an effect on subsequent rates of ingestion.

Feeding and physical characteristics of the leaf. Table II lists the water content and leaf toughness of the plant species and the average amount of each species eaten on the fifth day of the experiment. There does not appear to be any obvious trend relating either leaf toughness or water content to the amounts of leaf eaten. The only possibility may be indlicated by the fact that the toughest leaf, C. limon, was eaten the least.

TABLE II

Water content, leaf toughness, and amount of each species eaten on the fifth day of the experiment

Plant species

Bauhinia blakeana

Prunus domestica

Citrus limon

Hibiscus rosa-sinensis
Water content

(\% wet weight)

59.34

58.61

58.97

78.62
Leaf toughness

Amount eaten day 5

(g dry weight $/ 100$

units of body size)
3.91

3.12

1.46

2.67

\section{DISCUSSION}

Whatever it is about the composition or quality of the four leaf species that causes differences in the feeding behavior of $V$.irregularis, it must explain the following things: 1) why the grasshoppers ate more of a food after a period of getting used to it than they did when first exposed to the food, 2) why grasshoppers ate more food when given four species than they did when given a single species, 3) why grasshoppers ate different amounts when fed different single plant species 
and 4) why the food eaten at the beginning of the experiment influenced the quantity ingested when grasshoppers were given four different foods to choose from. Possible explanations include physical characteristics of the leaf species, nutritional differences among the leaf species used and differences between the plant species according to the nature of their plant secondary compounds. I will discuss each of these factors and attempt to determine which of them could lead to the observed feeding behaviors.

Water content did not seem to have any influence on the rate of ingestion of particular leaf species. Leaf toughness may have had some effect on the quantity eaten. Citrus was by far the toughest species and it was eaten less than the other species. However, this does not explain why the group fed Citrus continued to eat less than the other groups when given a choice of foods. The physical factors measured are those that have been shown to have some influence on grasshopper feeding behavior (Williams, 1954). These factors cannot explain the feeding patterns observed in the present experiments.

Nutritional differences between the leaf species were not tested for and the nutrient contents are not known. However, it does not seem that nutritional differences could explain some of the phenomena observed. If small quantities of Citrus were eaten because these leaves were nutritionally poor, it should be expected that grasshoppers fed this food would consume large quantities of leaves when given a choice of several kinds, to make up for what they missed out on when fed Citrus. Alternatively, grasshoppers may have eaten large quantities of $B$. blakeana because this food is nutritionally poor. If this were the case, it should be expected that these grasshoppers would then eat a smaller quantity of food when presented with four food choices. The observations do not confirm these expectations. When given four species of plant, grasshoppers that previously had been given only Bauhinia increased their consumption more than grasshoppers in the other groups, and those originally given Citrus exhibited the smallest increase (Fig. 1). Thus, nutritional factors alone cannot explain the observed feeding behaviors.

Leaves of Citrus are known to contain several volatile oils and a small concentration of alkaloid (Homburger \& Boger, 1968; Kesterson \& Hendrickson, 1953). Prunus leaves contain cyanogenic glycosides (Pammel, 1911) and some alkaloids (Raffauf, 1970). Hibiscus flowers have known insecticidal properties (Rao, 1958); the leaves contain an alkaloid and are used for various purposes in native herbal medicine (Watt \& Breyer-Brandwijk, 1962). The high tannin content in Bauhinia leaves has led to their use as an astringent (Watt \& Breyer-Brandwijk, 1962). All the plant secondary compounds mentioned exhibit some form of biological activity and the combination of toxins in each species is different from that of the others.

In eating these foods, grasshoppers should have to employ some form of biochemical degradation of the compounds in order to avoid suffering adverse physiological effects. These could be detoxification by the bacteria in the mid-gut caeca, detoxification via the grasshoppers' own mixed-function oxidases or both. These mechanisms are very similar to the mechanisms employed by mammals (Freeland 
\& Janzen, 1974; Smith, 1955). Because of this similarity, the limitations to these mechanisms in polyphagous grasshoppers should be the same as those found in mammals. These limitations to the mechanisms can also be expected to influence grasshopper feeding behavior in much the same way they do in mammals (Freeland \& Janzen, 1974; Freeland \& Winter, 1975). These behaviors include a gradual increase in rate of ingestion of a new food as the animal gets used to it, due to the gradual induction of enzymes or strains of bacteria to detoxify the food. They also include a greater total ingestion per unit time when an animal is feeding on several plants as opposed to a single plant food. These patterns were observed in the feeding experiments with $\boldsymbol{V}$. irregularis. Differing abilities to detoxify particular secondary compounds can explain the different rates of ingestion of different plant species.

The influence the first species fed to the grasshoppers had on subsequent ingestion of several plant species could be due to the effects of plant secondary compounds. Not only could $\boldsymbol{V}$. irregularis be a poor detoxifier of Citrus secondary compounds but the Citrus toxins could influence future success in detoxifying alternative foods. Enzymes or bacterial strains induced to detoxify Citrus oils could be very different from those used in detoxifying other secondary compounds. If the compounds present in two leaf species are closely related it may be easier for a grasshopper to eat one following experience with the other than it would be if the leaf species contained totally unrelated compounds. Further influence could come from Citrus toxins interacting synergistically with toxins from other species. This would necessitate a complete abandoning of Citrus before other plants could be eaten in large quantities. The presence of secondary compounds in plant species can explain the feeding behavior of caged $V$. irregularis.

Suggesting that secondary compounds may be important in acridid feeding behavior does not negate the proven importance of the leaf physical characteristics and nutrient content of leaves in grasshopper food selection. What it does do is help explain why grasshoppers are frequently observed to do better when feeding on a range of preferred food species than they do on a single preferred food (Dadd, 1963; Schoonhoven, 1973). Plant toxins can also be expected to play an important role in determining food preferences and in explaining the occurrence of food sampling and nibbling (Freeland, pers. obs.; Williams, 1954). In one case a $V$. irregularis was observed to fly to a $P$. domestica at 14.05 hours. On landing it chewed and swallowed Prunus bark from a young stem. This activity continued for half a minute and all the bark chewed was ingested. No additional food was eaten before sundown, when the grasshopper retreated to the base of the bush for the night. This same grasshopper was observed to feed extensively on Prunus the following morning. Freeland \& Janzen (1974) have hypothesized that polyphagous mammals have no accurate method of predicting by taste or smell the potential suitability of a plant they have never experienced. Rather than immediately consume large quantities of a new food, they should first sample a small portion and wait to determine their ability to detoxify the plant's secondary compounds. This 
system is based on learning via association of a plant taste and odor with either an adverse or non-adverse physiological stimulus resulting from ingestion of a food. These same arguments may apply to the acridids.

Mrs. L. Freeland was of great assistance with the field work and in carrying out the experiments. Mr. G. Monteith, Department of Entomology, University of Queensland, gave numerous helpful suggestions. D. Brambilla criticized the manuscript. The work was partially supported by NSF GB-35032X.

\section{RÉSUMÉ \\ COMPORTEMENT ALIMENTAIRE DE L'ACRIDIEN AUSTRALIEN VALANGA IRREGULARIS}

Des expériences ont été réalisées concernant l'alimentation de Valanga irregularis aux dépens des 4 espèces de plantes (Bauhinia blakeana, Prunus domestica, Citrus limon et Hibiscus rosa-sinensis) qu'il consomme habituellement dans la région où cette étude a été entreprise.

Il a été montré que la quantité de nourriture ingérée augmente de façon significative quand les insectes sont progressivement habitués à un type d'aliment. La quantité de nourriture mangée en un jour est fortement influencée par l'espèce de plante qui est consommée; cette dernière influence également de façon significative les consommations ultérieures, même quand on apporte aux insectes des nouvelles espèces de plantes au lieu d'une seule espèce.

Ces modalités du comportement alimentaire sont sans relation avec la dureté ou la teneur en eau des feuilles ou avec leur valeur nutritive; elles doivent cependant s'expliquer sur la base des hypothèses émises par Freeland \& Janzen (1974) à propos des mammifères phytophages. La présence de composés toxiques secondaires dans les espèces de plantes mangées peut expliquer les résultats des expériences, ces composés secondaires intervenant dans le choix de l'aliment et dans le comportement alimentaire.

\section{REFERENCES}

Bernays, E. A. \& Chapman, R. F. (1970). Experiments to determine the basis of food selection by Chorthippus parallelus (Zetterstedt) (Orthoptera: Acrididae) in the field. J. Anim. Ecol. 39 : 761-776.

CHAPMAN, R. F. (1957). Observations on the feeding of adults of the red locust (Nomadacris septemfasciata (Serville)). J. Anim. Behav. 5 : 60-75.

DaDD, R. H. (1963). Feeding behavior and nutrition in grasshoppers and locusts. Adv. Insect Physiol. 1: 47-111.

FEENY, P. P. (1970). Seasonal changes in oak leaf tannins and nutrients as a cause of spring feeding by winter moth caterpillars. Ecology 51: 565-581.

FreElAND, W. J. \& J JNZEN, D. H. (1974). Strategies in herbivory by mammals: the role of plant secondary compounds. Am. Nat. 108 : 269-289.

FreElAND, W. J. \& WiNTER, J. W. (1975). Evolutionary consequences of eating: Trichosurus vulpecula (Marsupialia) and the genus Eucalyptus. J. Chem. Ecol. (in press).

HoMBURGER, F. \& BOGER, E. (1968). The carcinogenicity of essential oils, flavors and spices: a review. Cancer Res. 28 : 2372-2374.

Kesterson, J. W. \& Hendrickson, R. (1953). Essential oils of Florida citrus. Fla. Agric. Exp. Sta. Bull. 521: 5-7. 
MulKeRn, G. B. (1967). Food selection by grasshoppers. Annu. Rev. Ent. 12 : 59-78.

Pammel, L. H. (1911). Manual of poisonous plants. Cedar Rapids, Iowa, The Torch Press. pp. 977.

PfaDt, R. E. (1949). Food plants, distribution and abundance of the big-headed grasshopper, Aulocara elliotti (Thos.). J. Kans. ent. Soc. 22 : 69-74.

RAFFAUF, R. F. (1970). A handbook of alkaloids and alkaloid containing plants. New York, Wiley-Interscience.

RaO, D. S. (1958). The insecticidal properties of several common plants of India. Econ. Bot. 12: 95-102.

SCHARFF, D. K. (1954). The role of food plants and weather in the ecology of Melanoplus mexicanus mexicanus (Sauss.). J. econ. Ent. 47: 485-489.

Schoontroven, L. M. (1973). Plant recognition by lepidopterous larvae. In: H. F. VAN EMDEN (Ed.): Insect/plant relationships, p. 87-99. New York, Wiley.

SMITH, J. N. (1955). Detoxication mechanisms in insects. Biol. Rev. 30 : 455-475.

WATT, J. M. \& BREYER-BRANDWIJK, M. G. (1962). The medicinal and poisonous plants of southern and eastern Africa. London, Livingston.

WHITE, M. J. D. (1968). A gynandromorphic grasshopper produced by double fertilization. Aust. J. Zool. 16 : 101-109.

Williams, L. H. (1954). The feeding habits and food preferences of Acrididae and the factors which determine them. Trans. $R$. ent. Soc. Lond. 105 : 423-454.

Williams, R. T. (1959). Detoxification mechanisms. New York, John Wiley and Sons. 